\title{
Optimizing the Performance of Porous Electrochemical Cells for Flue Gas Purification using the DOE method
}

Andersen, Kjeld Bøhm; Nygaard, Frederik Berg; He, Zeming; Menon, Mohan; Kammer Hansen, Kent

Published in:

Ceramics International

Link to article, DOI:

10.1016/j.ceramint.2010.11.006

Publication date:

2011

Link back to DTU Orbit

Citation (APA):

Andersen, K. B., Nygaard, F. B., He, Z., Menon, M., \& Kammer Hansen, K. (2011). Optimizing the Performance of Porous Electrochemical Cells for Flue Gas Purification using the DOE method. Ceramics International, 37(3), 903-911. https://doi.org/10.1016/j.ceramint.2010.11.006

\section{General rights}

Copyright and moral rights for the publications made accessible in the public portal are retained by the authors and/or other copyright owners and it is a condition of accessing publications that users recognise and abide by the legal requirements associated with these rights.

- Users may download and print one copy of any publication from the public portal for the purpose of private study or research.

- You may not further distribute the material or use it for any profit-making activity or commercial gain

- You may freely distribute the URL identifying the publication in the public portal 


\title{
Optimizing the performance of Porous Electrochemical Cells for Flue Gas Purification using the DOE method
}

\author{
Kjeld Bøhm Andersen*, Frederik Berg Nygaard, Zeming He, Mohan Menon, \\ Kent Kammer Hansen \\ Fuel Cells and Solid State Chemistry Division \\ Risø National Laboratory for Sustainable Energy \\ Technical University of Denmark (DTU) \\ DK-4000 Roskilde, Denmark
}

\begin{abstract}
The DOE model was used to improve the performance of cells for electrochemical gas purification.

Three factors were chosen: the amount of graphite, the Lanthanum Strontium

Manganate/Gadolinium-doped Cerium oxide weight \% ratio, and the Lanthanum Strontium

Manganate pre-calcination temperature (with or without Lanthanum Strontium Manganate

calcinated at $1000^{\circ} \mathrm{C}$ ). The effects of the following physical properties were measured: porosity, pore size, shrinkage, and conductivity. The sintered tapes were also characterised with scanning electron microscopy. Graphite was added as a pore former

The work shows, that a change in a factor not only changes the performance property that one would expect, but also influence other properties.
\end{abstract}

\footnotetext{
${ }^{*}$ Corresponding author. Tel: (45) 46775678, Fax: (45) 46775858, e-mail: kjan@risoe.dtu.dk
} 


\section{Introduction}

Exhaust from Diesel engines contains harmful compounds, such as $\mathrm{CO}_{2}(\mathrm{GHG}), \mathrm{CO}$, hydrocarbons (HC), soot and nitrogen oxides $\left(\mathrm{NO}_{\mathrm{x}}\right)$. The number of diesel driven vehicles is expected to increase in the future compared to gasoline powered engines ${ }^{[1,2,3]}$. At the same time the requirements of European standard will allow fewer emissions ${ }^{[4]}$. Therefore, the demand for diesel exhaust filters, capable of removing $\mathrm{NO}_{\mathrm{x}}$ and soot, is expected to increase drastically in the future.

Several techniques have been developed to reduce emissions from diesel fired engines, both for soot and $\mathrm{NO}_{\mathrm{X}}$. The most commonly used method for removing soot is by particulate filters or traps that can capture the particles in a porous structure. As particulates are continuously trapped in the filter the flow decreases. As the flow decreases the pressure and temperature increases to a point where the particulate matter is burned off (in some cases assisted by additives to the exhaust or other measures), and thereby cleaning the filter. These cycles occur continuously.

For reduction of $\mathrm{NO}_{\mathrm{X}}$, two technologies are used today: Selective Catalytic Reduction (SCR) and Exhaust Gas Recirculation (EGR). The SCR technology meets the requirements of Euro V-standard

${ }^{[5]}$, but uses noble metals such as Pt as catalysts rendering it relatively expensive. The EGR technology, on the other hand, is a simpler technology that does not require any noble metals. However, there is a fuel penalty associated with the operation of EGR and it does not fulfil the Euro $\mathrm{V}$-standard. Either of these technologies does not completely remove $\mathrm{NO}_{\mathrm{x}}$ from the exhaust. 
Electrochemical gas cleaning is based on selective membrane processes, where an electrical current (electrons) is used as a reagent. Such processes can be optimized to remove pollutants from exhaust gases in a more sustainable and economically advantageous way than the known traditional catalytic exhaust gas treatment methods. An electrochemical membrane consists of an electrolyte that separates a set of porous electrodes, just like a fuel cell. The electrolyte can conduct ions, but not electrons. The electrodes act as catalysts for the electrochemical reactions (see Figure 1). This type of system allows a portfolio of selective reactions to occur at the electrodes.

The electrochemical reduction of NO was at first proven possible in 1975 by Pancharatnam et al. ${ }^{[6]}$. Using a zirconia based oxide ion conducting electrolyte they reduced NO to elemental nitrogen and oxide anions on a Pt-electrode. The main obstacle with this technique is that the presence of oxygen lowers the activity of this type of system towards the reduction of NO and thereby increases the current consumption. Only a few known types of cathode materials can reduce NO in the presence of oxygen with a sufficiently high current efficiency. The main problems with the known electrode materials are that they are relative expensive or even toxic ${ }^{[7,8]}$.

Electrochemical oxidation of soot has been demonstrated by Dinex Filter Technology A/S ${ }^{[9-12]}$. The idea is to capture the soot in a porous structure consisting of an oxide ionic conducting electrolyte and a pair of electronic conducting ceramic electrodes. Reactive oxide anions are pumped to the anode where they react with the soot particles forming $\mathrm{CO}_{2}$. The electrochemical oxidation of hydrocarbons in an all solid state electrochemical cell has been studied by several authors. The main problem is that not all the hydrocarbons are converted to $\mathrm{CO}_{2}$, but that $\mathrm{CO}$ and partially oxidized hydrocarbons also are formed ${ }^{[13]}$. 
In principle, it is possible to combine all the processes in one filter as shown in figure 1 . The filter is porous and consists of alternating layers of electrodes and electrolyte. In Figure 1 a sketch is shown of a layered electrochemical filter to be used for removal of soot, hydrocarbons and $\mathrm{NO}_{\mathrm{X}}$. The driving force for the reactions is an external potential difference imposed between the top and the bottom of the filter. The filter converts NO to elemental nitrogen and oxide anions. The oxide anions generated, from the reduction of $\mathrm{NO}$, is used to oxidise the soot and the hydrocarbons. By using alternating current the electrodes are acting as both anodes and cathodes. A porous multilayered structure was developed for this application previously ${ }^{[14]}$. Porosity was found to be the critical micro structural parameter which controlled the flow rate and conductivity of the multilayer.

The design of experiments (DOE) ${ }^{[15]}$ method is a method to, in a controlled manner, to limit the amount of experiments. In this case we wish to optimize the performance of electrochemical cells for flue gas purification. Using the DOE method we optimize the porosity and microstructure of the electrochemical cell with respect to its performance. Porosity was introduced using graphite as a pore former or by changing the sintering properties of the layers by varying the composition and the calcination temperature of the constituent powders. The porosity, pore size and shrinkage during sintering of individual layers and the whole cell were varied to produce cells with optimized conductivity. DOE was used to quantify the effect of these variables on the measured properties. 


\section{Experimental}

\subsection{Preparation of suspensions and tapes}

Raw materials used in the present work were commercially available powders of $\mathrm{La}_{0.85} \mathrm{Sr}_{0.15} \mathrm{MnO}_{3}$ lanthanum strontium manganate (LSM15) (Haldor Topsoe A/S, Denmark) calcinated at $800^{\circ} \mathrm{C}$, $1000^{\circ} \mathrm{C}$ and $1200^{\circ} \mathrm{C}$ for $2 \mathrm{~h}, \mathrm{Ce}_{0.9} \mathrm{Gd}_{0.1} \mathrm{O}_{1.95}$ (CGO10) (Rhodia, France) and graphite (Alfa Aesar). Graphite was chosen as the pore former based on the result of earlier work ${ }^{[14]}$.

LSM15 was suspended in an azeotropic mixture of Methylethylketone and ethanol (MEKET) with Polyvinylpyrrolidone (PVP) as a dispersant and ball milled for $24 \mathrm{~h}$. CGO10 with PVP as dispersant, was then added to the suspension and the suspension was milled for further $24 \mathrm{~h}$. Finally, a mixture of binder, plasticizer and a release agent was added and the suspension milled for an additional $24 \mathrm{~h}$. The suspension was then tape casted, using at doctor blade adjusted in a 0.1 to $1.0 \mathrm{~mm}$ range.

After the tape had dried, the different layers were laminated together at described by Larsen et al ${ }^{[16]}$. Finally the laminate was sintered at $1250^{\circ} \mathrm{C}$. The laminate consists of alternating electrode layers and electrolyte layers. The final unit consists of 6 layers of electrode and 5 layers of electrolyte.

\subsection{Characterization of suspensions and tapes}

The particle size distribution (PSD) and viscosity of the suspensions were measured using a laser diffraction particle size analyzer (LS13320, Beckman Coulter, USA) after each milling step. Viscosity of the suspensions were measured on a Haake RheoStress 600 rheometer (Thermo- 
scientific, USA) using a parallel plate configuration with a separation between the plates of $0.5 \mathrm{~mm}$. The viscosity was measured on pre-sheared and rested suspensions as a function of increasing and decreasing shear rates. Suspensions were tape casted when desired values for the viscosity and PSD were achieved.

Shrinkage upon sintering of individual layers and the laminates were characterized by measuring the change in dimensions upon sintering. The pore size distribution and the porosity of sintered laminates and individual layers were characterized by mercury porosimetry (AutoPore IV, Micromeritics, USA). Flow through the layers and the laminates were measured using a home built instrument. A vacuum is applied on the laminate through a $3 \mathrm{~mm}$ diameter hose sealed with a $\mathrm{O}$ ring on the surface of the laminate. Any leak through the unit was then measured using a pressure gauge.

Fig. 2 shows four configurations that can be used for the measurement of in-plane resistivity.

Current is applied via parallel strips of conducting material, such as nickel felt $(\mathrm{A}, \mathrm{B})$, and the resulting potential is measured between two point probes $(C, D)$. The four terminal resistance, $R_{A B C D}$, is defined as:

$$
R_{A B C D}=\frac{V_{C D}}{I_{A B}}
$$

The volume resistivity of the film, $\rho$, is given by the formula:

$$
\rho=\frac{a d}{\ell} R_{A B C D}
$$

Equation 2

where $a$ is the width of the film (measured perpendicular to the current) $d$ is its thickness and $\ell$ is the distance between the potential probes. $\rho$ is expressed in units of $\Omega \cdot \mathrm{cm}$ or $\Omega \cdot \mathrm{m}$.

The conductivity was measured as described by F.W. Poulsen et al , ${ }^{[17]}$ and L. Kindermann, F.W. Poulsen and C. Bagger ${ }^{[18]}$. 
The micro-structure of the sintered laminated tapes was also characterized with scanning electron microscopy (SEM) using a Carl Zeiss 1540 XB scanning electron microscope.

\subsection{The Methodology}

To limit the amount of experiments the DOE method was use to optimize the conductivity and flow rate of the electrode layer. These properties depend on the porosity and the amount of LSM15 in the electrode layer. Porosity was controlled either by addition of graphite as pore-former or by addition of a LSM15 fraction calcined at $1000^{\circ} \mathrm{C}$ in the electrode layer. A sintering temperature of $1250^{\circ} \mathrm{C}$ was chosen based on previous investigations. Sintering at temperatures below $1250^{\circ} \mathrm{C}$ resulted in samples with low mechanical strength whereas temperatures above $1250^{\circ} \mathrm{C}$ resulted in an electrolyte with low flow rates. The sintering temperature was therefore fixed at $1250^{\circ} \mathrm{C}$ throughout this study. The composition of the electrolyte layer was not varied.

The experimental setup consisted of three factors with two levels each, resulting in eight or four experiments for full or fractional factorial design, respectively. Table 1 shows the experimental setup of the tapes. Tape no. 0 was the starting tape that was optimized. The graphite (factor A) is at level -1 $16 \mathrm{w} / \mathrm{w} \%$ and at factor $120 \mathrm{w} / \mathrm{w} \%$, the LSM15/CGO10 (factor B) weight ratio is at level 1 58:42 and at factor $\mathbf{1}$ 65:35 and the LSM15 treatment (factor C) is at level -1 with LSM15 calcined at $1000^{\circ} \mathrm{C}$ and at factor 1 without LSM15 calcined at $1000^{\circ} \mathrm{C}$. 


\section{Results and discussion}

\subsection{Experimental data}

The tape that we were optimizing, composition no. 0 , contained $11 \mathrm{w} / \mathrm{w} \%$ Graphite, had a $\mathrm{LSM} / \mathrm{CGO}$ ratio of $1: 1$ and the LSM were calcined at $800^{\circ} \mathrm{C}$ and $1000^{\circ} \mathrm{C}$ respectively and were mixed in the ratio $1: 1$. The fabrication of the unit is possible, but the performance of the unit has to be improved. It must have the ability to obtain a sufficient exhaust flow, have a pore size that complies with the size of the soot particles and at the same time have the ability to withstand the physically handling during exposure and electrochemical performance (e.g. $\mathrm{NO}_{\mathrm{x}}$ removal rate)

To improve the current solution, we chose the amount of graphite added as pore former as the first factor, the ratio between LSM15 and CGO10 as the second factor and the third factor as the composition of the LSM part in terms of the calcination temperature of the LSM15. The ratio between the different calcinated temperature of the LSM powders are always unity. Other factors could also have been chosen, but these three are used. Since the main purpose of changing the composition is to get more porosity and pore size, the $\mathrm{Hg}$-pore size measurements are assembled in Fig. 3. Table 2 shows the results of the properties of all the 5 tapes. Note that flow rate do not change from tape 1 to 4 , but that is changes from tape 0 to tape 1 to 4 . It shows that the flow rate is improved, when optimizing the electrochemical cells. However, the difference in flow rate between tape 1 to 4 is not detectable within the method used here, so the variation will not be disused further. 
From the date in table 2 it is seen, that both porosity, pore size and flow rate are improved by increasing the amount of graphite added. It also shows that the porosity increases with increasing amount of graphite. With the DOE method it is now possible to see how the variation of the precursors influences the physical properties of the electrochemical cells.

\subsection{DOE data.}

From the results in table 2, it is possible to calculate the formulas according to the DOE method:

$$
\begin{array}{cc}
\text { Porosity }=54.07+5.30 \times \mathrm{A}+(-1.86) \times \mathrm{B}+0.48 \times \mathrm{C} & \text { Equation } 3 \\
\text { Pore size }=0.94+0.05 \times \mathrm{A}+0.05 \mathrm{xB}+0.08 \times \mathrm{C} & \text { Equation } 4 \\
\text { Shrinkage }=26.10+0.40 \mathrm{xA}+(-0.30) \times B+0.08 \times \mathrm{C} & \text { Equation 5 } \\
\text { Porosity }=5.53+(-0.43) \times \mathrm{A}+2.18 \times \mathrm{xB}+1.08 \times \mathrm{C} & \text { Equation 6 }
\end{array}
$$

Where $\mathrm{A}, \mathrm{B}$ and $\mathrm{C}$ is either 1 or -1 .

Table 3 show the results in the data of the 8 DOE tapes. A, B, and C is defined in table $1 . \mathrm{A}, \mathrm{B}$ and C can have the value -1 or 1 , depending on the choice of what value the factors are set to. The results could be analyzed from the perspective of a single property if there is a wish to change that, but the whole idea behind this setup of the experiments is to see how different properties are affected by changes in one or several factors. 


\subsection{Changing factors in the DOE model}

To illustrate how the performance varied when changing the factors and how the starting point influence the results, two scenarios will be disused in the following. The first will start with all factors set to level 1 and the second will start with all factors set to level -1 (see the setup row)

With the DOE method it is possible to see the effect of a change in one of the factors.. I.e. we can change only the graphite content, $(\mathrm{A}, \mathrm{B}, \mathrm{C})=(-1,1,1)$ and $(1,1,1)$. This is done for all three factors giving the following results: $(A, B, C)=(1,1,1),(-1,1,1),(1,-1,1)$ and $(1,1,-1)$. All other that we are looking at is in this case kept at level 1. If only one factor is changed at a time, it will be possible to see the effect and what properties are affected. i.e. we can change only the graphite content, (A, B, C) $=(-1,-1,-1)$ and $(1,-1,-1)$. This is done for all three factors giving the following results:

$(A, B, C)=(-1,-1,-1),(1,-1,-1),(-1,-1,1)$ and $(-1,1,-1)$. All other factors than the one we are studying are in this case kept at level -1 .

\subsection{Porosity and pore size}

Table 4 shows, when the start factors are +1 , that when the amount of pore former is increased from 16 to 20 weight $\%$, the porosity increases from 47.40 to $58 \%$, the pore size increases from 1.02 to $1.12 \mu \mathrm{m}$. Table 4 also shows, when the factors are set to -1 as starting point, that when the amount 
of pore former is increased, the porosity increases from 50.14 to $60.75 \%$, and the pore size increases from 0.77 to $0.87 \mu \mathrm{m}$. Therefore, the results for the increased amount of graphite are, as expected, that the porosity increases. But at the same time the pore size increases. Note that the changes in \%-points are only dependent on the change in amount of graphite, but the absolute values are very much dependent on the starting composition. So the porosity increases 18 to $22 \%$ and the pore size increases 9 to $13 \%$, when increasing the amount of graphite.

When changing the LSM15/CGO10 ratio the properties are also changed. By changing from 58/42 to $65 / 35$, when all factors are +1 as a starting point, the porosity is decreased from 61.71 to $58 \%$, and the pore size increases from 1.02 to $1.12 \mu \mathrm{m}$. When all the factors are -1 as a starting point, changing from $58 / 42$ to $65 / 35$, the porosity is decreased from 50.14 to $46.43 \%$, the pore size increases from 0.77 to $0.87 \mu \mathrm{m}$. Also for the LSM15/CGO10 ratio the change is dependent on the change in ratio, and the absolute values are depending on the starting values of the factors. So the porosity decreases 6 to $7 \%$ and the pore size increases 9 to $13 \%$, when increasing the LSM15/CGO10 ratio.

When changing the LSM15 composition, the properties are also changed. The porosity seems not to change by using the LSM15 calcinated at $1000^{\circ} \mathrm{C}$ or not. The pore size increases from 0.97 to 1.12 $\mu \mathrm{m}$, when we do not use LSM15 calcinated at $1000^{\circ} \mathrm{C}$, when all factors are +1 as starting value, and the pore size changing from 0,77 to $0,92 \mu \mathrm{m}$. Also for the LSM15/CGO10 ratio the change is dependent on the change in ratio, and the absolute values are depending on the starting values of the factors. So the porosity decrease $2 \%$ and the pore size increases to 15 to $19 \%$, when the LSM 15 composition is changed. 
What we want to do is to vary the physical properties by changing the composition of the factors. The effects have been described above, but to get a clear picture of the result of the experiments, the results will be described from the physical behaviour of the ceramic. How this can be done will be shown in the following.

\section{Porosity:}

The porosity is influenced by the amount of graphite and the LSM15/CGO10 ratio. The porosity will be increased by increasing the amount of graphite and by decreasing the LSM15/CGO10 ratio. The porosity can be decreased by decreasing the amount of graphite and increasing the LSM15/CGO10 ratio. A change in LSM composition will not influence the porosity. In the tested contents, the porosity was changed $2.65 \%$ points when the amount of graphite is changed $1 \%$ point. The porosity was $0.53 \%$ points when the LSM 15 percentage was changed $1 \%$ point.

\section{Pore size:}

The pore size will be influenced by all three factors used. It will be increased by increasing the amount of graphite, by increasing the LSM15/CGO10 ratio and by making a LSM15 competition without LSM15 calcinated at $1000^{\circ} \mathrm{C}$. And it will be decreased by decreasing the amount of graphite, by decreasing the LSM15/CGO10 ratio and by making a LSM15 competition with LSM15 calcinated at $1000^{\circ} \mathrm{C}$. In the tested contents, the pore size changes $0.10 \mu \mathrm{m}$, when changing from the low value to the high value for all three factors. 


\subsection{Shrinkage and Conductivity}

For the Shrinkage and the Conductivity, the change in values are related to the change made, but the actually value is very much depending on the starting point of the factors, as were the case for the porosity and the pore size.

Table 4 shows, that when the amount of pore former is increased the linear shrinkage increases from 26.20 to $27 \%$, and the conductivity decreases from 9.20 to $8.35\left(\mathrm{~S}^{*} \mathrm{~m}\right)^{-1}$, when all factors have the start value +1 . And the linear shrinkage increases from 25.20 to $26 \%$, and the conductivity decreases from 2.70 to $1.85\left(\mathrm{~S}^{*} \mathrm{~m}\right)^{-1}$, when all factors have the start value -1 . Therefore, the results for the increased amount of graphite are, the shrinkage is not affected significantly, but the conductivity decreases from 9 to $30 \%$ and the shrinkage is relatively unaffected.

When changing the LSM15/CGO10 ratio, the properties are also changed. By changing from 58/42 to $65 / 35$, and all factors starts at +1 , the shrinkage decreases from 27.60 to $27.00 \%$, and the conductivity increases from 4.0 to $8.35\left(\mathrm{~S}^{*} \mathrm{~m}\right)^{-1}$, and when all factors starts at -1 , the shrinkage decreases from 25.2 to $24.6 \%$, and the conductivity increases from 2.7 to $7.05\left(\mathrm{~S}^{*} \mathrm{~m}\right)^{-1}$. By increasing the amount of LSM the conductivity increases as expected. It increases by 109 to $261 \%$. The shrinkage is not affected significantly.

When changing the LSM15 composition, the properties are also changed. The shrinkage increases from 25.20 to $27.00 \%$, and the conductivity increases from 6.20 to $8.35\left(\mathrm{~S}^{*} \mathrm{~m}\right)^{-1}$ at all factors at value +1 , and the shrinkage increases from 25.20 to $26.80 \%$ and the conductivity increases from 2.70 to $4.85\left(\mathrm{~S}^{*} \mathrm{~m}\right)^{-1}$ at all factors at starting value -1 , when we do not use LSM15 calcinated at 
$1000{ }^{\circ} \mathrm{C}$. By changing from compositions from containing LSM15 calcinated at $1000{ }^{\circ} \mathrm{C}$ to compositions not containing LSM15 calcinated at $1000^{\circ} \mathrm{C}$ the conductivity increases. It increases by 35 to $80 \%$. The shrinkage is increased $6 \%$ independent of the starting value of the factors.

\section{Shrinkage:}

The shrinkage is only influenced significantly, from the results in this work, by the composition of the LSM15 powder.

\section{Conductivity:}

The conductivity is influenced by all three factors. The conductivity will be increased by decreasing the amount of graphite, by increasing the LSM15/CGO10 ratio and by only having LSM15 calcinated at $800^{\circ} \mathrm{C}$ and $1200^{\circ} \mathrm{C}$. The conductivity was decreased by increasing the amount of graphite, decreasing the LSM15/CGO10 and by introducing LSM15 calcinated at $1000^{\circ} \mathrm{C}$. In the tested contents, the conductivity was changed $0.21\left(\mathrm{~S}^{*} \mathrm{~m}\right)^{-1}$ when the amount of graphite is changed $1 \%$. The conductivity was $0.62\left(\mathrm{~S}^{*} \mathrm{~m}\right)^{-1}$ when the LSM percentage was changed $1 \%$. The conductivity was changed $2.15\left(\mathrm{~S}^{*} \mathrm{~m}\right)^{-1}$ depending of, if LSM calcinated at $1000^{\circ} \mathrm{C}$ was present.

\subsection{SEM}

The micro-structure of the four laminated sintered tapes can be found in Figures 4 to 7 . The electrodes are seen to consist of two different type of particles, CGO10 (white) and LSM (black). In general the porosity of the sintered tapes is high. It is also seen that CGO10 and LSM is well mixed in the structure. With regard to changes in the micro-structure as a function of changes in the 
composition of the tapes, mainly two effects are observed. If LSM calcinated at $1000{ }^{\circ} \mathrm{C}$ is added to the tapes the mean particle size of LSM, after sintering, decreases. If a high ratio between LSM and CGO10 is used the mean pore size increases. This is partly confirmed by the mercury porosimetry measurements.

\subsection{The total variation}

Table 5 shows the variation in the properties that can be achieved within the range of this work according to the DOE results. The results show, that it is possible to get porosity from 46.43 to $61.71 \%$, the pore size can be varied from 0.77 to $1.12 \mu \mathrm{m}$, which is $46 \%$, the shrinkage from 24.6 to $27.6 \%$, which is $12 \%$, and the conductivity can be changed from 1.85 to $9.20\left(\mathrm{~S}^{*} \mathrm{~m}\right)^{-1}$. It is almost $400 \%$. All percentages are calculated in reference to the lowest value. This range is, as shown in this work, due to the fact, that the properties are changed by two or all three factors. And the changes are, for the major parts of the properties, a significant change. So this work shows that by changing one factor, several properties will be affected.

This work helps us to determine the changes in properties when changing the factors, and it also helps us to choose the right composition for at given sets of properties.

\subsection{Choosing a composition}

If we i.e. want the highest porosity, but we still need a fair conductivity then it can be seen from table 4 , that it is very important to choose the right composition to get the optimized properties. If we chose $(A, B, C)=(1,-1,-1)$ we get a porosity on $60.75 \%$ and a conductivity of only $1.85\left(\mathrm{~S}^{*} \mathrm{~m}\right)^{-}$ 
${ }^{1}$ but if we chose $(A, B, C)=(1,-1,1)$, we get almost the same porosity $(61.71 \%)$, but here we get a conductivity of $4\left(\mathrm{~S}^{*} \mathrm{~m}\right)^{-1}$ more than double the conductivity. If a porosity on $58 \%$ is sufficient, we can obtain a conductivity on $8.35\left(\mathrm{~S}^{*} \mathrm{~m}\right)^{-1}$ by choosing $(\mathrm{A}, \mathrm{B}, \mathrm{C})=(1,1,1)$. The choice also influences the pore size. $(A, B, C)=(1,-1,-1)$ gives a pore size on $0.87 \mu \mathrm{m}$, by choosing $(A, B, C)=(1,-1,1)$ we get a pore size on $1.02 \mu \mathrm{m}$, and if we chose $(A, B, C)=(1,-1,-1)$, we get a pore size on $1.12 \mu \mathrm{m}$.

The three different options all have a high content of pore former. Both the LSM15/CGO10 ratio and the LSM15 composition have a significant influence on the properties of the result. If we focus on the shrinkage to be as low as possible, from table 4, there are three compositions to consider that gives shrinkage around $25 \%$. The three compositions are $(A, B, C)=(-1,-1,-1)$ with shrinkage on 25.2 $\%,(A, B, C)=(-1,1,-1)$ with a shrinkage on $24.6 \%$ and $(A, B, C)=(1,1,-1)$ with a shrinkage on 25.4 . If we chose $(A, B, C)=(-1,-1,-1)$, we get a porosity on $50.14 \%$ a pore size of $0.77 \mu \mathrm{m}$ and a conductivity on $2.70\left(\mathrm{~S}^{*} \mathrm{~m}\right)^{-1}$. Instead, if we choose $(\mathrm{A}, \mathrm{B}, \mathrm{C})=(1,-1,1)$ we get a decrease in porosity to $46.43 \%$, an increase in pore size to $0.87 \mu \mathrm{m}$ and a significant increase in conductivity to $7.05\left(\mathrm{~S}^{*} \mathrm{~m}\right)^{-1}$. Finally, if we consider to use $(\mathrm{A}, \mathrm{B}, \mathrm{C})=(1,-1,-1)$ as the solution, we get a much higher porosity of $57.03 \%$, an increased pore size of $0.97 \mu \mathrm{m}$, but the conductivity will decrease compared to $(A, B, C)=(1,-1,1)$ but still higher than $(A, B, C)=(-1,-1,-1)$. So when one wants less shrinkage, it gives a very different result depending on how we chose to do so.

The shrinkage is improved by increasing the LSM15/CGO ratio, where by the conductivity also is improved. A change in porosity does not influence the performance significantly.

This work started due to the wish to get a solution with a higher pore size and porosity. The need for the pore size was 2 to $3 \mu \mathrm{m}$, porosity on at least $45 \%$ and a flow over $35 \mathrm{ml} / \mathrm{min}$. The pore size 
was $0.5 \mu \mathrm{m}$ and the porosity was $27 \%$ and the flow around $20 \mathrm{ml} / \mathrm{min}$. During the work it was concluded, that the conductivity should be as high as possible, due to the fact that it was seen that this property could vary quite a bit depending on the composition.

To get the highest conductivity as possible, we can chose between $(A, B, C)=(1,1,1)$ and $(A, B, C)=$ $(-1,1,1)$ meaning LSM15/CGO10 ratio on $65 / 35$ and not using LSM15 calcinated at $1000^{\circ} \mathrm{C}$ and use either 16 or $20 \%$ Graphite of pore former in the slurry. According to Table 4 we will get a higher porosity, a pore size with $20 \%$ Graphite, but also a slightly lower conductivity and it will probably be a weaker ceram. Instead by choosing $16 \%$ Graphite, we get at better conductivity and sufficient porosity. Also we will probably get a higher strength, which will be an issue in the future work, since the produced ceramic are very brittle and have insufficient strength for the purpose for the use for this ceramic unit.

\section{Summary}

The purpose of this work is to improve the physical performance of developed unit for reducing emissions from diesel fired engines. To do this, we have used the DOE method to achieve more information on how to do this. 
The range that are tested, are defined by the factors. The three factors that are used in this work are amount of graphite (16 w/w \% and $20 \mathrm{w} / \mathrm{w} \%)$, the LMS15/CGO10 ratio (58/42 and 65/35), and variation in LSM15 pre-calcination temperature (with or without LSM15 calcinated at $1000^{\circ} \mathrm{C}$ ). The physical properties that varies when changing the content of the factors are the porosity in $\%$, the pore size in $\mu \mathrm{m}$, the shrinkage in $\%$, and the conductivity in $\left(\mathrm{S}^{*} \mathrm{~m}\right)-1$.

The results show, that it is possible to get porosity from 46.43 to $61.71 \%$, the pore size can be varied from 0.77 to $1.12 \mu \mathrm{m}$, which is $46 \%$, the shrinkage from 24.6 to $27.6 \%$, which is $12 \%$, and the conductivity can be changed from 1.85 to $\left.9.20\left(\mathrm{~S}^{*} \mathrm{~m}\right)^{-1}\right)$, which is almost $400 \%$. All percentages are calculated in reference to the lowest value.

This work also demonstrate how the results of the DOE give us at tool, how to choose the right composition with different wishes for the physical performance of the produced unit. The chosen composition for the future work is LSM15/CGO10 ratio on 65/35 and not using LSM15 calcinated at $1000^{\circ} \mathrm{C}$ and use $16 \%$ Graphite of pore former in the slurry.

\section{Acknowledgements}

Carl Thyden is thanked for help with the scanning electron microscopy. This work was supported by Det Strategiske forskningsråd project number of 2104-05-0067 


\section{References}

1 C. Seguin (2006) Diesel car sales set to overtake petrol in Europe. www.pwc.com

2 http://www.acea.be/images/uploads/pub/20040212PublicationsWhyDiesel.pdf

3.http://www.acea.be/images/uploads/st/20080129_EU\%20Motor\%20Vehicles\%20in\%20use\%202

006.pdf

4 http://ec.europa.eu/enterprise/automotive/pagesbackground/pollutant_emission/index.htm

5 http://www1.eere.energy.gov/vehiclesandfuels/pdfs/deer_2004/session11/2004_deer_joubert2.pdf

6. S. Pancharatnam, R.A. Huggins, D.M. Mason, J. Electrochem. Soc. 122869 (1975)

7. K. Iwayama, X. Wang, Appl. Catal. B: Environmental, 19137 (1998)

8. K. Hamamoto, Y. Fujishiro, M. Awano, J. Electrochem. Soc., 153 D167 (2006)

9. H. Christensen, S.S. Nissen, J. Dinesen, SAE technical paper no. 1998-05-47 (1998).

10. H. Christensen, J. Dinesen, H.H. Engell, K. Kammer Hansen, SAE technical paper no. 1999-010472 (1999).

11. H. Christensen, J. Dinesen, H.H. Engell, L.C. Larsen, E.M. Skou, K. Kammer Hansen, SAE technical paper no. 2000-01-0478 (2000).

12. H. Christensen, Z.S. Rak, Catal. Today, 75451 (2002)

13. M. Stoukides, Catal. Rev.-Sci. Eng., 421 (2000)

14 . Z. He, K. B. Andersen, L. Keel, F. B. Nygaard, M. Menon, K. K. Hansen, Ionics, 15427

(2009) 
15. Z. J. S. Kim and J. W. Kalb, "Design of Experiments: An Overview and Application Example", Medical Device \& Diagnostic Industry Magazine, March 1996, p. 78.

16. P.H.Larsen, K.Brodersen, US2008/0124502 A1 (2008)

17. F.W. Poulsen, P. Buitink and B. Malmgren-Hansen, Van der Pauw and conventional 2-point conductivity measurements on YSZ plates, Proc. 2nd Intl. Symp. on Solid Oxide Fuel Cells (SOFC-II), Athens 1991, eds: F. Grosz, P. Zegers, S.C. Singhal, and O. Yamamoto, Office for Official Publications of the EC, Brussels (1991).

18. L. Kindermann, F.W. Poulsen and C. Bagger, In-plane conductivity of Ni-cermet anodes, DKSOFC-R25 Marts 1998 (PM-16). 
List of Tables

Table 1 - Setup of the experimental tapes. The three factors varied are the amount of graphite, the ratio between LSM15 and CGO10 and the calcinations temperature of LSM15.

Table 2 - The results of the experiments.

Table 3 - Results of the DOE in the 8 different configurations.

Table 4 - All factors set to level 1 and then one factor is changed at the time.

Table 5 - Variation of the different properties of the sintered tapes. 
Table 1.

\begin{tabular}{|c|c|c|c|c|}
\hline Tape & A: & $\begin{array}{c}\text { B: LSM15 } \\
\text { ICGO10 } \\
\text { G Graphite }\end{array}$ & $\begin{array}{c}\text { C: } \\
\text { LSM15 }\end{array}$ & Description \\
No. 0 & 0 & 0 & 0 & 11\% graphite, 50:50 LMS15/CGO10, with \\
treatment & LSM15_1000 \\
\hline No. 1 & -1 & -1 & -1 & $16 \%$ graphite, 58:42 LMS15/CGO10, with \\
\hline No. 2 & -1 & 1 & 1 & LSM15_1000 ${ }^{\circ} \mathrm{C}$ \\
\hline No. 3 & 1 & -1 & 1 & LSM15_1000 ${ }^{\circ} \mathrm{C}$ \\
\hline No. 4 & 1 & 1 & -1 & $20 \%$ graphite, 58:42 LMS15/CGO10, without \\
\hline
\end{tabular}


Table 2.

\begin{tabular}{|c|c|c|c|c|c|}
\hline Tape & Porosity \% & Pore size $\mu \mathrm{m}$ & Shrinkage \% & Flow rate $\mathrm{ml} / \mathrm{min}$ & ${\text { Conductivity }\left(\mathrm{S}^{*} \mathrm{~m}\right)^{-1}}^{-1}$ \\
\hline No. 0 & 27 & 0,5 & 27,80 & 20,0 & - \\
\hline No. 1 & 50.14 & 0.77 & 25.20 & 37.3 & 2.70 \\
\hline No. 2 & 47.40 & 1.02 & 26.20 & 37.5 & 9.20 \\
\hline No. 3 & 61.71 & 1.02 & 27.60 & 37.5 & 4.00 \\
\hline No. 4 & 57.03 & 0.97 & 25.40 & 37.5 & 6.20 \\
\hline
\end{tabular}


Table 3.

\begin{tabular}{|c|c|c|c|c|c|c|}
\hline A & B & C & Porosity $\%$ & Pore size $\mu \mathrm{m}$ & Shrinkage \% & ${\text { Conductivity }\left(\mathrm{S}^{*} \mathrm{~m}\right)^{-1}}^{-1}$ \\
\hline 1 & 1 & 1 & 58.00 & 1.12 & 27.00 & 8.35 \\
\hline 1 & 1 & -1 & 57.03 & 0.97 & 25.40 & 6.20 \\
\hline 1 & -1 & 1 & 61.71 & 1.02 & 27.60 & 4.00 \\
\hline 1 & -1 & -1 & 60.75 & 0.87 & 26.00 & 1.85 \\
\hline-1 & 1 & 1 & 47.40 & 1.02 & 26.20 & 7.05 \\
\hline-1 & 1 & -1 & 46.43 & 0.92 & 24.60 & 4.85 \\
\hline-1 & -1 & 1 & 51.11 & 0.87 & 26.80 & 2.70 \\
\hline-1 & -1 & -1 & 50.14 & 0.77 & 25.20 & \\
\hline
\end{tabular}


Table 4.

\begin{tabular}{|c|c|c|c|c|c|c|c|c|c|c|c|}
\hline Factors & & \multicolumn{2}{|c|}{ Porosity \% } & \multicolumn{2}{|c|}{ Pore size $\mu \mathrm{m}$} & \multicolumn{2}{|c|}{ Shrinkage \% } & \multicolumn{2}{|c|}{ Conductivity $\left(S^{*} \mathrm{~m}\right)-1$} & \multicolumn{2}{|c|}{ Setup } \\
\hline \multicolumn{2}{|c|}{ All factors set to } & +1 & -1 & +1 & -1 & +1 & -1 & +1 & -1 & +1 & -1 \\
\hline \multirow{3}{*}{$\begin{array}{c}\text { Graphite } \\
\text { Weight \% }\end{array}$} & 16 & 47.40 & 50.14 & 1.02 & 0.77 & 26.20 & 25.20 & 9.20 & 2.70 & $(1,1,1)$ & $(-1,-1,-1)$ \\
\hline & 20 & 58.00 & 60.75 & 1.12 & 0.87 & 27.00 & 26.00 & 8.35 & 1.85 & $(-1,1,1)$ & $(1,-1,-1)$ \\
\hline & Difference & 10.60 & 10.60 & 0.10 & 0.10 & 0.80 & 0.80 & -0.85 & -0.85 & & \\
\hline \multirow{3}{*}{$\begin{array}{l}\text { LSM15 } \\
\text { /CGO10 } \\
\text { weight \% }\end{array}$} & $58 / 42$ & 61.71 & 50.14 & 1.02 & 0.77 & 27.60 & 25.20 & 4.00 & 2.70 & $(1,1,1)$ & $(-1,-1,-1)$ \\
\hline & $65 / 35$ & 58.00 & 46.43 & 1.12 & 0.87 & 27.00 & 24.60 & 8.35 & 7.05 & $(1,-1,1)$ & $(-1,1,-1)$ \\
\hline & Difference & -3.71 & -3.71 & 0.10 & 0.10 & -0.60 & -0.60 & 4.35 & 4.35 & & \\
\hline \multirow{3}{*}{$\begin{array}{c}\text { LSM15 } \\
\text { calcinated } \\
\text { at } 1000^{\circ} \mathrm{C}\end{array}$} & With & 57.03 & 50.14 & 0.97 & 0.77 & 25.40 & 25.20 & 6.20 & 2.70 & $(1,1,1)$ & $(-1,-1,-1)$ \\
\hline & Without & 58.00 & 51.11 & 1.12 & 0.92 & 27.00 & 26.80 & 8.35 & 4.85 & $(1,1,-1)$ & $(-1,-1,1)$ \\
\hline & Difference & 0.97 & 0.97 & 0.15 & 0.15 & 1.60 & 1.60 & 2.15 & 2.15 & & \\
\hline
\end{tabular}


Table 5.

\begin{tabular}{|c|c|c|c|c|c|}
\hline Variation & Porosity \% & Pore size $\mu \mathrm{m}$ & Shrinkage \% & Flow rate $\mathrm{ml} / \mathrm{min}$ & Conductivity $1 /\left(\mathrm{S}^{*} \mathrm{~m}\right)$ \\
\hline Min & 46.43 & 0.77 & 24.6 & 37.3 & 1.85 \\
\hline Max & 61.71 & 1.12 & 27.6 & 37.5 & 9.20 \\
\hline Difference in \% & 32.9 & 45.5 & 12.2 & 0.5 & 397.3 \\
\hline
\end{tabular}




\section{List of figures}

Figure 1. Schematic drawing of the electrochemical unit. The unit is seen to consist of alternating layers of electrode and electrolyte.

Figure 2. Configuration used for measuring the in-plane resistivity of a film.

Figure 3. Results of the $\mathrm{Hg}$ measurements.

Figure 4. Micro-graph of a sintered cell of tape 1. Light phase is CGO10 and dark phase is LSM. It is seen that the electrode is highly porous, and that CGO10 and LSM is well mixed within the structure.

Figure 5. Micro-graph of a sintered cell of tape 2. Light phase is CGO10 and dark phase is LSM. It is seen that the electrode is highly porous, and that CGO10 and LSM is well mixed within the structure.

Figure 6. Micro-graph of a sintered cell of tape 3. Light phase is CGO10 and dark phase is LSM. It is seen that the electrode is highly porous, and that CGO10 and LSM is well mixed within the structure.

Figure7. Micro-graph of a sintered cell of tape 4. Light phase is CGO10 and dark phase is LSM. It is seen that the electrode is highly porous, and that CGO10 and LSM is well mixed within the structure. 
Figure 1.

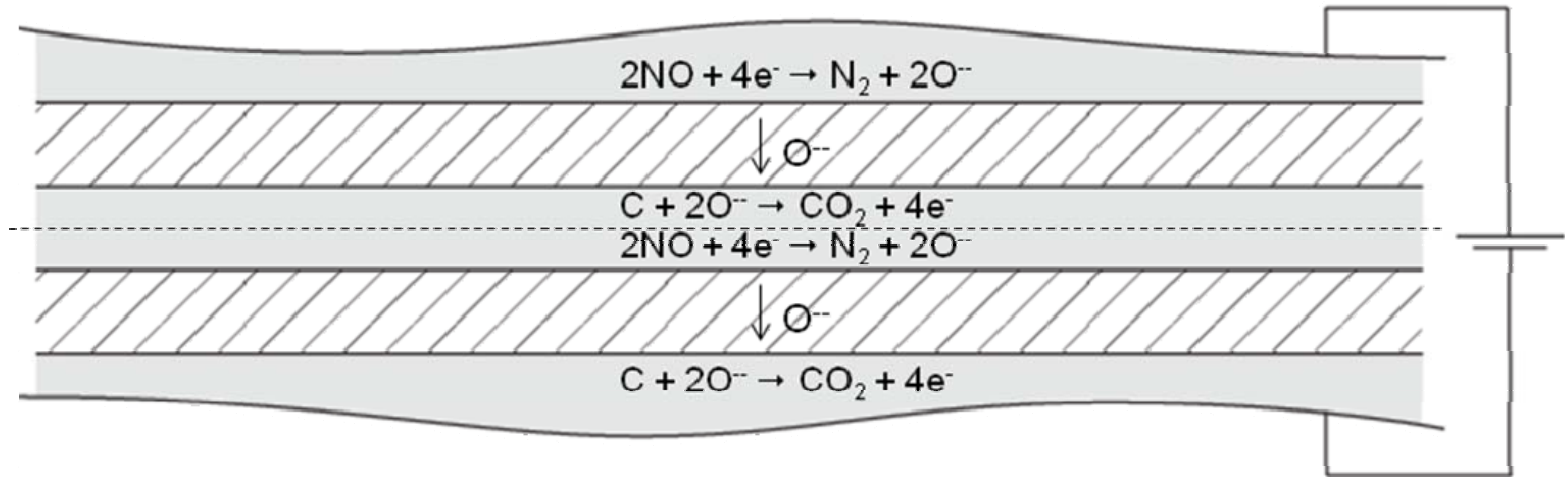


Figure 2.

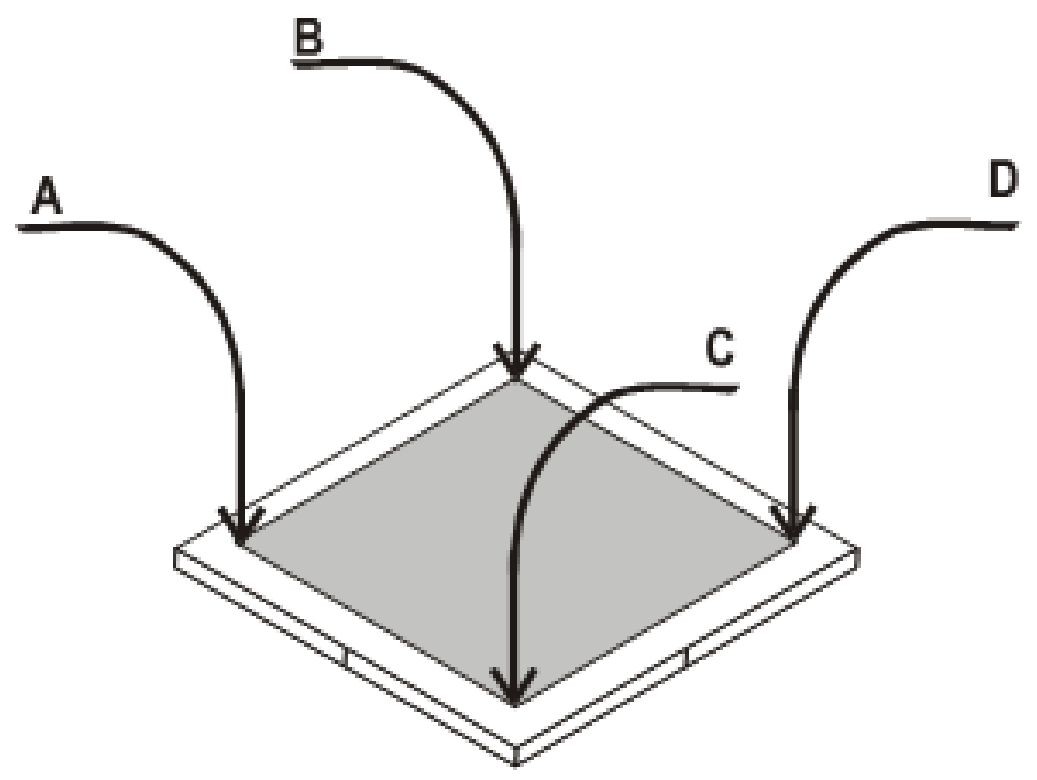


Figure 3.

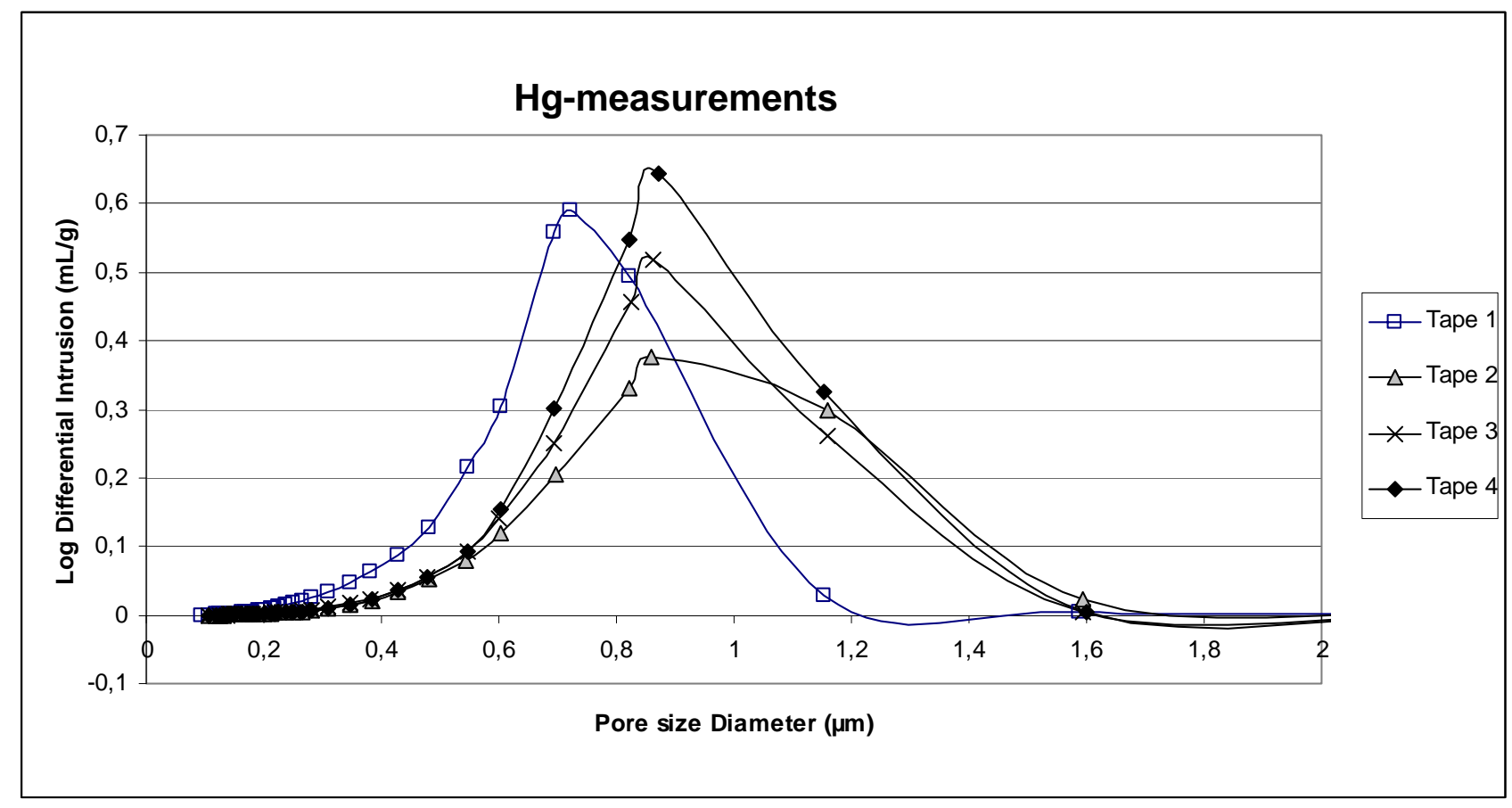


Figure 4.

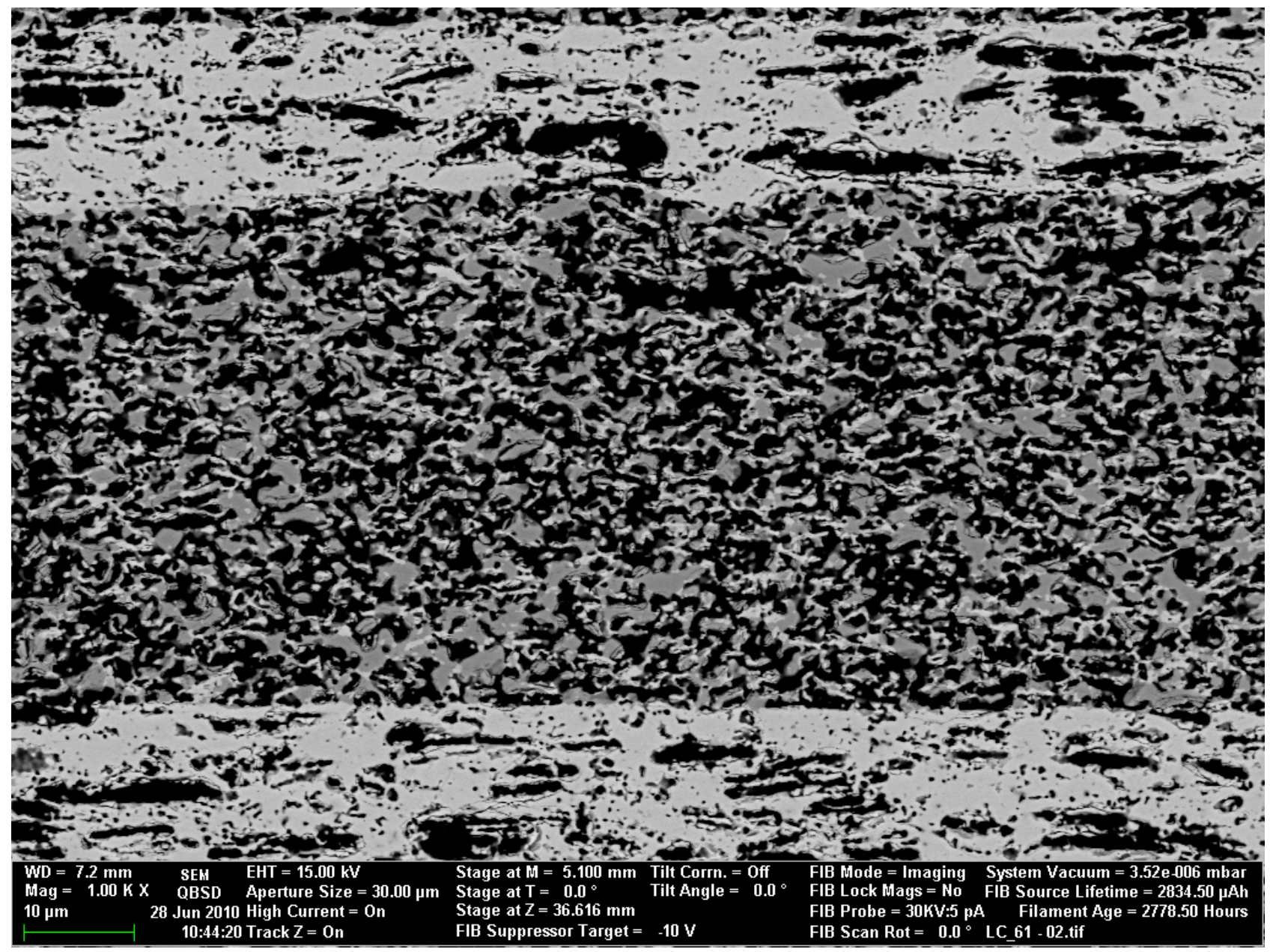


Figure 5.

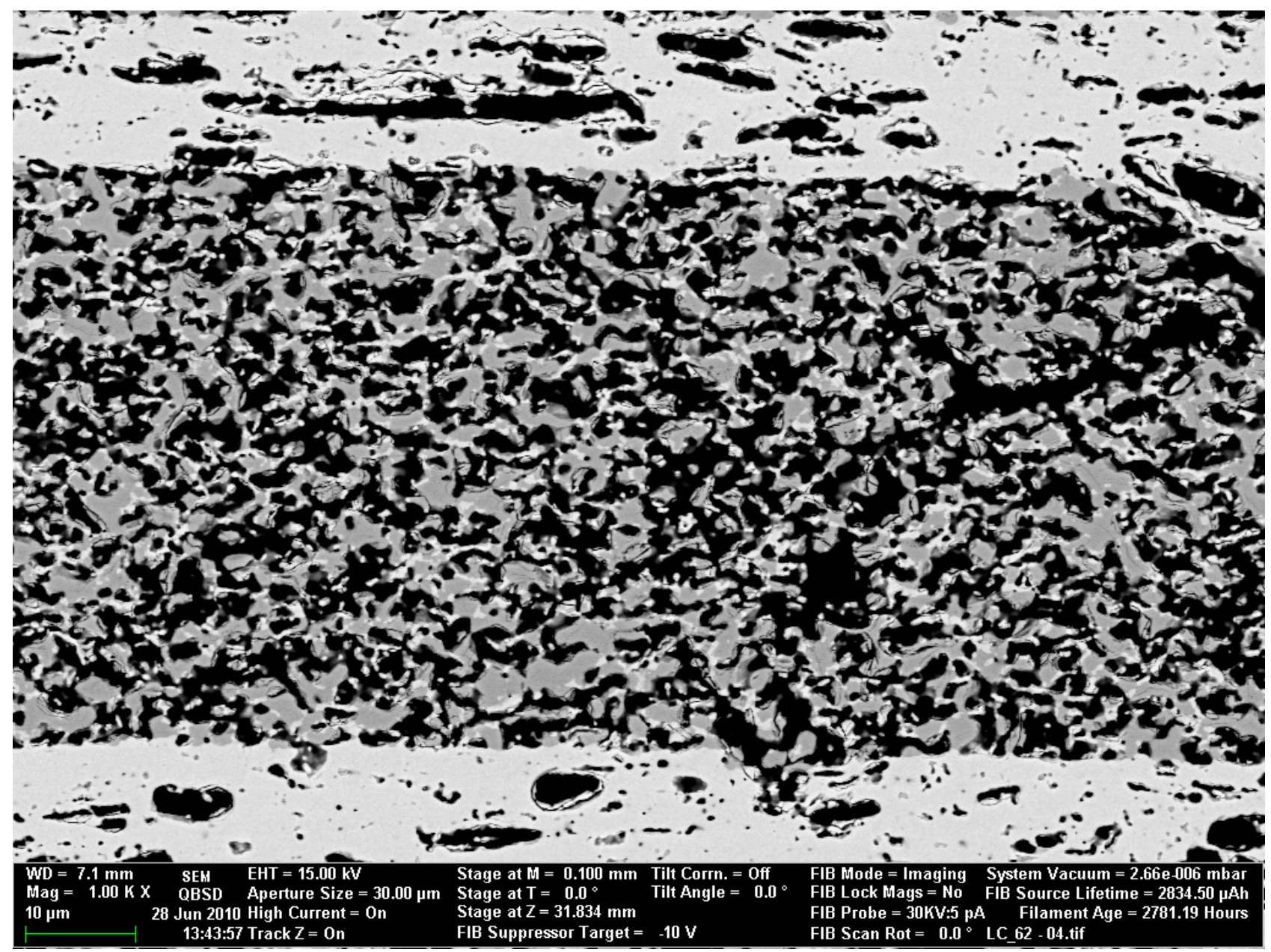


Figure 6.

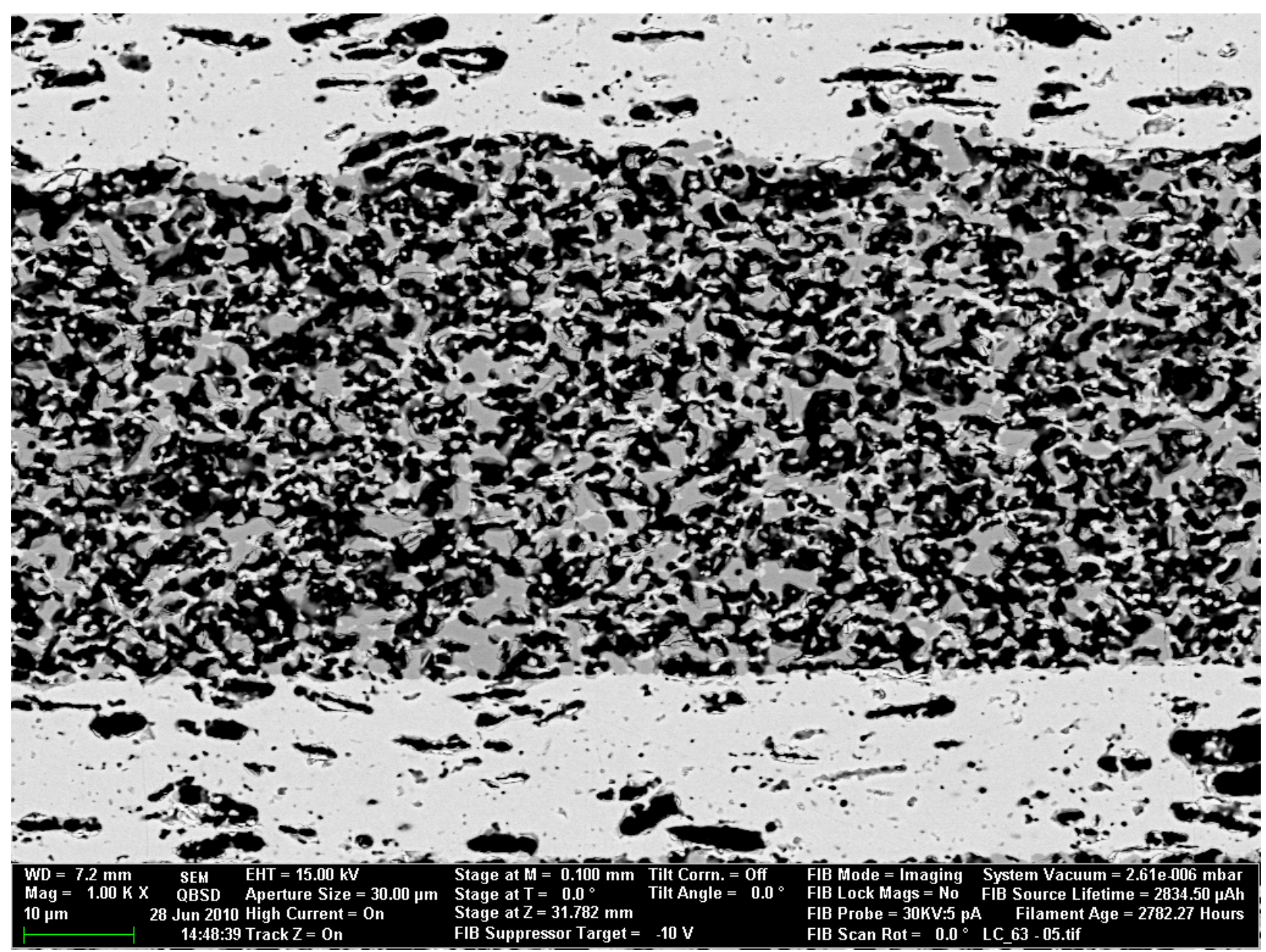


Figure 7.

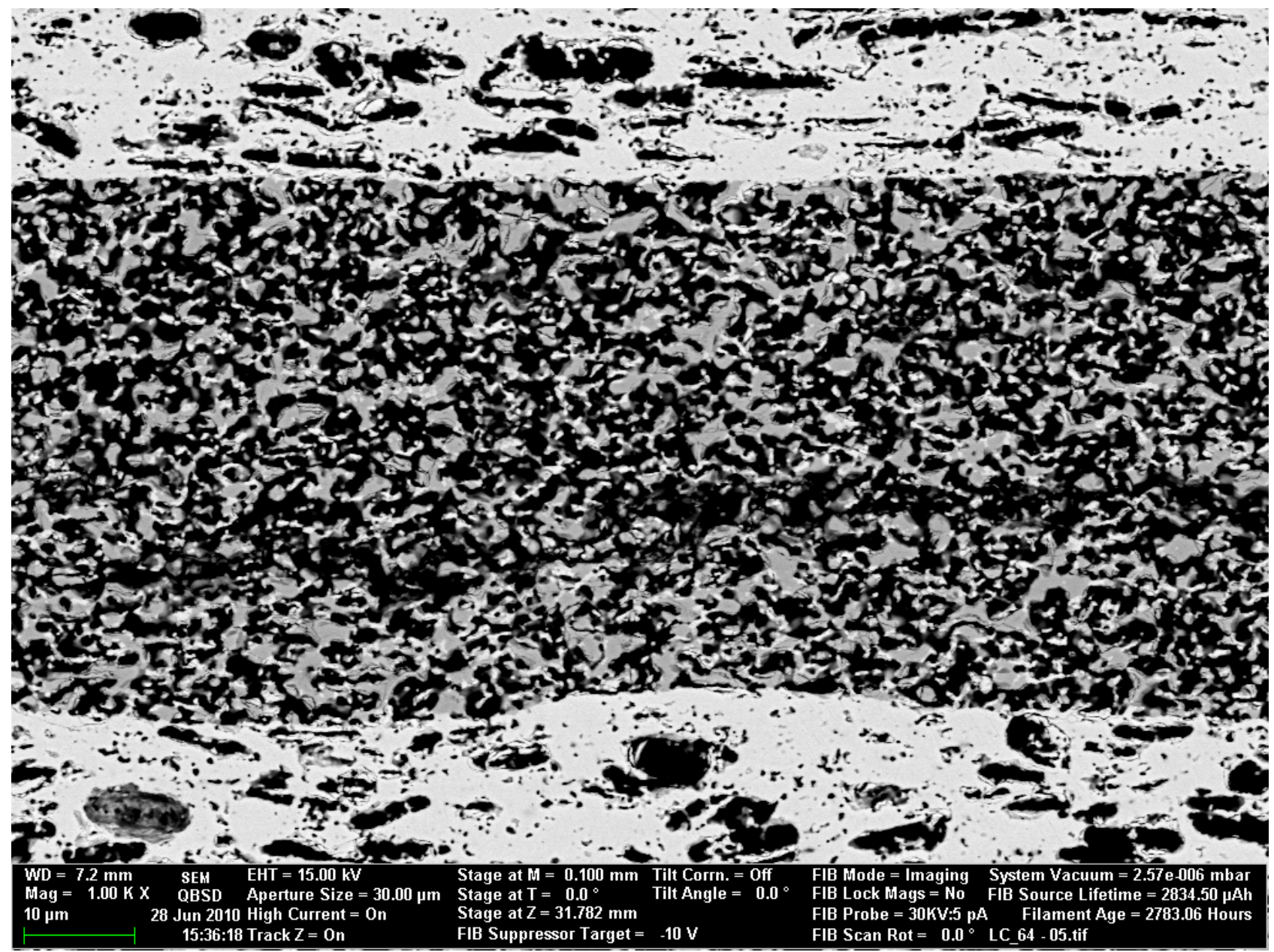

